\title{
Postdigital Scholarly Publishing
}

\author{
Tina Besley ${ }^{1}$
}

Accepted: 28 June 2021 / Published online: 12 July 2021

(c) The Author(s), under exclusive licence to Springer Nature Switzerland AG 2021

Keywords Academic publishing - Academic journal $\cdot$ Scholarly journal · Postdigital $\cdot$ Henry Oldenburg $\cdot$ Philosophical Transactions

\section{Introduction}

In our postdigital times, scholarly publishing undergoes rapid change. Speaking of knowledge production, this change includes the rise of peer production, collaboration, and collective intelligence (Peters et al. 2020) and collective approaches to research, writing, and peer review (Peters et al. 2021). Speaking of knowledge dissemination, 'the third age of the journal as an electronic, interactive and mixedmedia form of scientific communication' (Peters et al. 2016: 1401) brings about challenges from knowledge presentation to knowledge delivery. At the fringes between knowledge production and dissemination lies political economy, which strongly influences all aspects of knowledge work.

These days, scholarly publishing is heavily standardized and profit oriented. In words of Michael Peters: 'The pervasiveness of the monograph and the scientific article is a product of an industrial age. I say to my students "the article is a dirty little industrial machine," trying to make the point about homogenization and standardization of scientific thought.' (Peters and Jandrić 2018: 291) These trends negatively impact knowledge-making as a whole, and in our postdigital age, there is a growing need to transcend these problems and offer new forms of scholarly publishing.

This editorial presents recent efforts in establishing a new postdigital publishing ecosystem: PESA Agora. ${ }^{1}$ Starting with a very brief genealogy of the academic journal and the trajectory that has seen the establishment of PESA Agora, the editorial summarizes our experience in establishing a new platform for postdigital scholarly publishing and offers some suggestions for the future.

\footnotetext{
1 See https://pesaagora.com/. Accessed 27 June 2021.
}

Tina Besley

tbesley@bnu.edu.cn

1 Beijing Normal University, Beijing, People's Republic of China 


\section{The Academic Journal}

The academic journal began in 1665 in the UK with The Philosophical Transactions of the Royal Society ${ }^{2}$ published and edited by Henry Oldenburg, the Royal Society's first secretary and is the world's first and longest running journal.

Oldenburg spun his wide-ranging network of European natural-philosophical contacts, the activity of the Royal Society, and his skills as a linguist and scientific editor into a new form of print intended to promote the enterprise of early modern science and perhaps make some money on the side. The journal appeared monthly, selling for one shilling. (The Royal Society 2021a)

The Royal Society website provides us with some interesting historical detail, but it is important note just how this path-breaking journal began. Oldenburg's editorial for the first issue of Philosophical Transactions, titled 'An introduction to this tract', offers the following abstract:

Whereas there is nothing more necessary for promoting the improvement of Philosophical Matters, than the communicating to such, as apply their studies and endeavours that way, such things as are discovered or put in practise by others; it is therefore thought fit to employ the press as the most proper way to gratifie those, whose engagement in such studies, and delight in the advancement of learning and profitable discoveries doth entitle them to the knowledge of what this Kingdom, or other parts of the World, do, from time to time, afford, as well of the progress of the studies, labours, and attempts of the curious and learned in things of this kind, as of their compleat discoveries and performances. (The Royal Society 1665)

In Oldenburg's day, The Charter of the Royal Society was dedicated to 'improving natural knowledge'. By early nineteenth century, however, Philosophical Transactions was facing increased competition.

The Royal Society responded by introducing more rigorous and systematic expert peer review, and by launching an abstract journal, Proceedings of the Royal Society, procedures which were reinforced and extended during the long tenure of George Gabriel Stokes as editor. Later in the century Philosophical Transactions split into 'A' and 'B' series (physical and biological sciences respectively), and from 1893 the Proceedings began to include full research papers in its own right. (The Royal Society 2021b)

By the twentieth century, the academic journal, as the cornerstone of the emerging global system of scientific communication and scholarship, was closely tied to peer review and the history of the printing industry. The 1960s and 1970s saw major commercial publishers acquiring journals from learned societies. This has continued apace, and has been strengthened by the turn to online publication. Since 2000s, the field is

\footnotetext{
${ }^{2}$ See https://royalsocietypublishing.org/journal/rstl. Accessed 27 June 2021.
} 
dominated by five major companies that have grown enormously through acquisitions and mergers (Elsevier, Springer, Taylor and Francis, Wiley-Blackwell, Sage).

The traditional business model has been where academics supply articles and peer reviews free of charge, but the journal is behind a paywall where the publisher charges fees to readers - individually, or in bundles sold to worldwide libraries. If a learned society owns the journal, they will provide an Editor and editorial management team and will receive negotiated royalties. This model extracts work of publicly funded research institutions, and turns it into profit for commercial publishers (Jackson et al. 2018: 97).

Dramatic shifts are facing academic publishing in the twenty-first century as changes in Internet-based technologies shift it from being solely print based to being in electronic formats and now adds in digital media, video, and links with new social media. All the while now being hugely influenced by the development and use of algorithms to establish many forms of bibliometrics and analytics, including impact factor and citation analysis (e.g., Scopus, SSCI, Web of Science, Google Scholar) and various databases (e.g., EBSCOhost, PubMed Central, Science Direct, ERIC). This contributes to now ubiquitous use of standardized measurement of research excellence, ${ }^{3}$ which stands in stark opposition to creative knowledge work (Peters and Besley 2013).

\section{PESA Agora}

Our attempt at disrupting this state of the art started from our engagement in mainstream publishing. The Philosophy of Education Society of Australasia (PESA) ${ }^{4}$ owns the journal Educational Philosophy and Theory (EPAT) ${ }^{5}$ which was established in 1969. It was a typical journal of a learned society, starting very small with a couple of issues per year until 1999. Once Michael A. Peters became Editor-inChief, he systematically expanded the number of issues from 3 issues a year until 2001 to 14 in 2014 and thereafter. In 2019, EPAT had more downloads than the first 30 years, and in 2020, it experienced a $100 \%$ increase in submissions. EPAT is still largely behind a paywall, but its editorials are now free access as are some articles. PESA members have full access and the membership fees have remained low for many years. Royalties generated over many years have enable PESA to take more control over its activities.

In May 2019, Michael and I walked across for coffee to a favourite café opposite Beijing Normal University, talking about a new concept of the academic journal. Rather than relying on any of the big publishers, the new journal would be in PESA's ownership and control and would be accessible to all readers, not just academics. The

\footnotetext{
${ }^{3}$ For in-depth critique of these developments, see Special Issue of Postdigital Science and Education, 'Measuring Excellence' in Higher Education, https://link.springer.com/journal/42438/volumes-andissues/3-1. Accessed 27 July 2021.

4 See https://pesa.org.au/. Accessed 27 June 2021.

5 See https://www.tandfonline.com/toc/rept20/current. Accessed 27 June 2021.
} 
new platform, PESA Agora, is designed to build a new kind of journal that would be in a more popular, journalistic style that would appeal to a much wider audience than the traditional Philosophy of Education arena and its academic journals. We also wanted a location which could incorporate the Access: Contemporary Issues in Education $^{6}$ archive. Andrew Madjar digitized the archive of 39 print issues of Access, as we realised that it should not be left to languish in the stacks of three universities (Auckland, AUT, and RMIT), but become visible and available to all.

We took our idea to a PESA Executive meeting in Auckland July 2019 which agreed to establish and fund two Open Access journals: PESA Agora as a new multimedia online journal, and a relaunch of Access: Contemporary Issues in Education. This resulted in a diverse online platform that houses three separate but connected publishing spaces-PESA Agora, Access, and Open Access EPAT editorials. The platform was launched in July 2020, with the following mission statement:

PESA Agora provides a public space for comments on issues and concerns related to the philosophy of education, the wider fields of education, and culture in our contemporary world. PESA Agora is an Open Access meeting place for people interested in the intersections of education, philosophy, teaching, learning, technology, indigenous philosophies, identity issues, and the environment, in effect it is the future of the academic journal. (PESA Agora 2020) (emphases original)

The concept for PESA Agora is derived from the ancient Agora of Athens which was an open marketplace for the polis or citizens to trade goods and where they gathered to speak in public about the artistic, spiritual, and political life. The Agora served as an early model for both the Academy and the dialogues, and PESA Agora is set up as a postdigital public space for sharing ideas through postdigital dialogue (Jandrić et al. 2019). To date, PESA Agora has published contributions by PESA members and wider. It serves a rapidly growing number of communities from all over the world, including the Postdigital Science and Education (PDSE) community, who regularly publish their articles, book announcements, and calls.

\section{Postdigital Art of Words}

EPAT published the mission statement article for PDSE (Jandrić et al. 2018) and has supported postdigital research since its very beginnings. Yet both EPAT and PDSE work within the oligopoly of commercial academic publishers (the first with Taylor and Francis; the latter with Springer Nature) and have limited space for manoeuvre. In order to move from theory to practice of developing new forms of academic publishing, we have extended one foot out of mainstream publishing by developing PESA Agora and have left the other foot in mainstream publishing with the learned society ownership model, strong links to EPAT, and excellent working relationships with other mainstream journals such as PDSE.

\footnotetext{
${ }^{6}$ See https://pesaagora.com/access-journal/. Accessed 27 June 2021.
} 
This is a typical postdigital move- the new publishing model recognizes tensions between various publishing models, but refuses to succumb to either-or dichotomies and seeks development at a higher plane of their co-existence. Furthermore, this approach adds an important practical aspect to our initial thoughts on the postdigital as 'both a rupture in our existing theories and their continuation' (Jandrić et al. 2018: 895).

According to Geoff Cox, 'the ruptures produced [by the postdigital] are neither absolute nor synchronous, but instead operate as asynchronous processes, occurring at different speeds and over different periods and are culturally diverse in each affected context' (Cox 2014). Indeed, our new publishing system was made possible by strong support from an established learned society, PESA, a leading journal in educational philosophy and theory, and EPAT, and a large community of excellent scholars built around them over the years. A different postdigital publishing project, starting without such support and in different circumstances, may acquire a very different format.

It is also worthwhile to mention that asynchronicity described by Cox transcends large historical periods. For instance, relationships between PESA and its learning society PESA Agora are closer to relationships between The Royal Society and The Philosophical Transactions of the Royal Society in Henry Oldenburg's day than to today's relationship between PESA and Educational Philosophy and Theory. Postdigital ruptures are inseparable from postdigital continuations; future developments can often be inspired by not-so-recent history.

At her speech in acceptance of the National Book Foundation Medal for Distinguished Contribution to American Letters, Ursula K. Le Guin said:

Developing written material to suit sales strategies in order to maximise corporate profit and advertising revenue is not the same thing as responsible book publishing or authorship. ... Books aren't just commodities; the profit motive is often in conflict with the aims of art. We live in capitalism, its power seems inescapable - but then, so did the divine right of kings. Any human power can be resisted and changed by human beings. Resistance and change often begin in art. Very often in our art, the art of words. (Le Guin 2014)

Scholarly publishing is also an art, and a lot of our argument against mainstream publishing indeed stems from the logic of capitalism. Yet together with fiction, scholarly communication is much older than capitalism, and will surely outlive capitalism.

New postdigital challenges require new postdigital models of scholarly publishing. Starting from the art of our own words, PESA Agora offers one possible model. This model is contextual and will not suit all people or circumstances. Yet now that PESA Agora has reached its first birthday, I used the opportunity to summarize that experience and draw some lessons for the future of postdigital scholarly publishing. 


\section{References}

Cox, G. (2014). Prehistories of the post-digital: Or, some old problems with post-anything. A PeerReviewed Journal About, 3(1). https://doi.org/10.7146/aprja.v3i1.116087.

Jackson, L., Peters, M. A., Benade, L., Devine, N., Arndt, S., Forster, D., Gibbons, A., Grierson, E., Jandrić, P., Lazaroiu, G., Locke, K., Mihaila, R., Stewart, G., Tesar, M., Roberts, \& Ozoliņs, J. (2018). Is peer review in academic publishing still working?. Open Review of Educational Research, 5(1), 95-112. https://doi.org/10.1080/23265507.2018.1479139.

Jandrić, P., Knox, J., Besley, T., Ryberg, T., Suoranta, J., \& Hayes, S. (2018). Postdigital Science and Education. Educational Philosophy and Theory, 50(10), 893-899. https://doi.org/10.1080/00131857. 2018.1454000.

Jandrić, P., Ryberg, T., Knox, J., Lacković, N., Hayes, S., Suoranta, J., Smith, M., Steketee, A., Peters, M. A., McLaren, P., Ford, D. R., Asher, G., McGregor, C., Stewart, G., Williamson, B., \& Gibbons, A. (2019). Postdigital Dialogue. Postdigital Science and Education, 1(1), 163-189. https://doi.org/10.1007/ s42438-018-0011-x.

Le Guin, U. K. (2014). Speech in Acceptance of the National Book Foundation Medal for Distinguished Contribution to American Letters. https://www.ursulakleguin.com/nbf-medal. Accessed 27 June 2021.

PESA Agora (2020). About. https://pesaagora.com/about-pesa-agora/. Accessed 27 June 2021.

Peters, M. A., \& Besley, T. (Eds.). (2013). The Creative University. Rotterdam: Sense.

Peters, M. A., \& Jandrić, P. (2018). The Digital University: A Dialogue and Manifesto. New York: Peter Lang.

Peters, M. A., Besley, T., Jandrić, P., \& Zhu, X. (Eds.). (2020). Knowledge Socialism. The Rise of Peer Production: Collegiality, Collaboration, and Collective Intelligence. Singapore: Springer.

Peters, M. A., Tesar, M., Jackson, L., Besley, T., Jandrić, P., Arndt, S., \& Sturm, S. (2021). The Methodology and Philosophy of Collective Writing. Abingdon and New York: Routledge.

Peters, M. A.; Jandrić, P; Irwin, R.; Locke, K.; Devine, N.; Heraud, R.; Gibbons, A.; Besley, T.; White, J.; Forster, D.; Jackson, L.; Grierson, E.; Mika, C.; Stewart, G.; Tesar, M.; Brighouse, S.; Arndt, S.; Lazariou, G.; Mihalia, R.; Bernade, L.; Legg, C.; Ozolins, J.; Roberts, P. (2016). Toward a Philosophy of Academic Publishing. Educational Philosophy and Theory, 48(14), 1401-1425. https://doi. org/10.1080/00131857.2016.1240987.

The Royal Society (1665). An introduction to this tract. The Philosophical Transactions of the Royal Society, 1(1), 1-2. https://doi.org/10.1098/rstl.1665.0002.

The Royal Society (2021a). Philosophical Transactions. https://royalsocietypublishing.org/journal/rstl. Accessed 27 June 2021.

The Royal Society (2021b). About Philosophical Transactions. https://royalsocietypublishing.org/rstl/ about. Accessed 27 June 2021. 